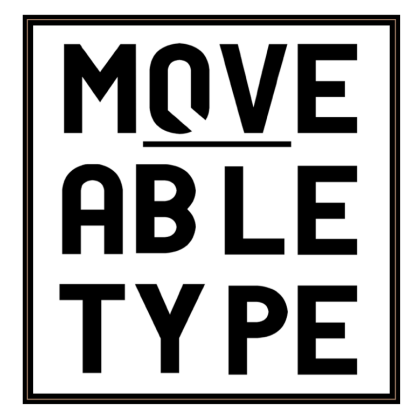

'Ambience and the 'Symbiotic Real': An Ecocritical Reading of It Must Have Been Dark. By Then'

Author[s]: Seb Rolley

Source: Moveable Type, Vol.13, 'Ambience' (2021)

DOI: $10.14324 / 111.1755-4527.112$

MoveableType is a Graduate, Peer-Reviewed Journal based in the Department of English at UCL.

(C) $2021 \mathrm{Seb}$ Rolley. This is an Open Access article distributed under the terms of the Creative Commons Attribution License (CC-BY) 4.0https://creativecommons.org/licenses/by $/ 4.0 /$, which permits unrestricted use, distribution, and reproduction in any medium, provided the original author and source are credited. 


\section{Ambience and the 'Symbiotic Real': An Ecocritical Reading of It Must Have Been Dark By Then}

Seb Rolley

The suggestion that a crucial response to the unfolding damage of the Anthropocene might be to develop a feeling of solidarity with spoons is undeniably a little weird. Why, in an age of mass extinction, might we need to focus on feeling a deep and meaningful connection with a piece of cutlery? This, however, is exactly the project taken up in Timothy Morton's Humankind (2017), their book seeking to develop non-discriminate solidarity with non-human entities, of which cutlery is just one example. Morton has become one of the foremost ecological critics writing today, underpinning their work with Object-Oriented Ontology (OOO) and its radical disruption of anthropocentric notions of being. ${ }^{1}$ In Humankind, Morton takes their ontological approach to ecocriticism and applies it to Marxism, a largely anthropocentric mode of thought, looking to rehabilitate Marxist ideals into offering an ecological, non-anthropocentric way of existing in the world. For Morton, the anthropocentrism of Marxist thought is a 'bug' to be removed, 'not a feature.'2 Morton's project in Humankind provides an exciting new perspective on ecocriticism, one I see as having an as-yet untapped relationship with theories of ambience.

This essay draws on Morton's ecological Marxism in dialogue with the ambient poetics of the Ambient Literature Project, viewing them as parallel fields which can be usefully folded into one another to develop their common ground. The Ambient Literature Project was a 'thirty-month research ... project led by Professor Jon Dovey at the University of the West of England's Digital Cultures Research Centre' which focused on investigating 'situated writing practices in which text is able to respond to the site of reading'; what they term "ambient literature". ${ }^{3}$ The project had multiple outcomes, including a critical book containing academic perspectives on ambience and ambient literature, empirical research on locational technologies and literary form, and the production of three creative texts. This essay draws heavily from the academic work contained within Ambient Literature (2021),

\footnotetext{
1 For an overview of OOO see: Graham Harman, Object-Oriented Ontology A New Theory of Everything (London: Pelican Books, 2018).

${ }^{2}$ Timothy Morton, Humankind (London: Verso, 2017), p. 7.

3 Jonathan Dovey, Tom Abba, and Kate Pullinger, 'Introduction', in Ambient Literature, ed. by Tom Abba, Jonathan Dovey, and Kate Pullinger (London: Palgrave Macmillan, 2021), p. 5.
} 
establishing links between the writing of Jonathon Dovey and Matt Hayler and the ecocriticism of Morton by deploying one of the project's creative ambient texts, It Must Have Been Dark By Then (2017, IMHBD) by Duncan Speakman, as its primary case study. $I M H B D$ is an unusual literary experience in that it requires the reader to engage with both a printed book and an app on their smartphone, with the latter both creating a digital map as the story progresses and providing a soundtrack of narration, instruction, field recordings, and original music. IMHBD's generative map guides the reader to walk through whichever location they choose to situate their reading / listening, layering experiences from areas around the world affected by environmental crises onto this situated literary experience. As Hayler puts it when he introduces the text in his chapter 'Objects, Places, and Entanglements', 'the themes of the narrative often emerge subtly as the reader, script, and audio narration dance around one another with planned steps and room for interpretation'. ${ }^{4}$ This unique multimodality and locationality allows the text to develop an interesting relationship with ambience and ecology that underpins this essay's analysis.

In 'Critical Ambience', Dovey and Hayler engage with this relationship, drawing attention to $I M H B D$ as evidence of how 'ambient cultural practices can be reframed as critically focused experiences'. ${ }^{5}$ This stance undermines prevailing views of ambient media as simply 'either passive backgrounds or immersive entertainment', positions often underpinned by Brian Eno's assertion that Ambient Music 'must be as ignorable as it is interesting'. ${ }^{6}$ Their analysis of IMHBD explores how the critically focused experiences cultivated by the text might be used to engage with ecology and environment by analysing, critiquing, and extending Morton's application of ambient poetics in Ecology Without Nature (2009). Throughout the book, Morton attempts to establish ways of reading which reject an anthropocentric image of "nature" and replace it with an ecological understanding of the world. As a part of these new ecocritical reading practices, Morton evokes ambience and its associations with being surrounded 'to make strange the idea of environment', a use which Dovey and Hayler take to be about 'articulating a sense of how subjects and environments are coconstituted ...reaching towards new subjectivities that escape the Cartesian self. ${ }^{7}$ They readily admit, however, that Morton's use of ambience remains

\footnotetext{
4 Matt Hayler, 'Objects, Places, and Entanglements', in Ambient Literature, ed. by Tom Abba, Jonathan Dovey, and Kate Pullinger (London: Palgrave Macmillan, 2021), p. 87.

${ }^{5}$ Jonathan Dovey and Matt Hayler, 'Critical Ambience', in Ambient Literature, ed. by Tom Abba, Jonathan Dovey, and Kate Pullinger (London: Palgrave Macmillan, 2021), p. 141.

${ }^{6}$ Ibid., p. 141.; Brian Eno, Music for Airports / Ambient 1 (LP Liner Notes) (London: Polydoor, 1978).

7 Timothy Morton, Ecology without Nature (Massachusetts: Harvard University Press, 2009), p. 34.; Dovey and Hayler, 'Critical Ambience', p. 150.
} 
'ambiguous' and 'often at odds with itself', something which they navigate by reconsidering its use through the lens of the critical ambience developed in $I M H B D .^{8}$

In the 10 years between the publication of Ecology Without Nature and Humankind the connection between ambience and ecological thought apparently disappeared from Morton's writing. Ambience's disappearance in this period was arguably because of the ambiguous and contradictory nature identified by Hayler and Dovey, with Morton never fleshing out their ambient poetics so that they would be usefully transferrable into future works. However, I see 'Critical Ambience' as doing this work of fleshing-out the ecological potential of ambience through its engagement with $I M H B D$. By elucidating ambience's ecocritical potential, Dovey and Hayler refigure ambience so that it might be usefully rehabilitated back into working with Morton's project in Humankind.

This essay's "folding-in" of Morton and the Ambient Literature Project, which this critical refiguring of ambience facilitates, reveals ambience as a phenomenon uniquely suited to attuning us to the radical ecological ontology outlined in Humankind. My use of "attuning" in this essay draws both on the idea of 'being co-constituted by our environments' raised by Dovey and Hayler and Morton's use of "tuning” to describe a recognition of ourselves as ecological beings in Being Ecological (2018). ${ }^{9}$ I therefore extend the work done by Hayler and Dovey in exploring ambient literature's ecological potential by applying their claim that ' $I M H B D$... fulfils the conditions for environmentally aware modes of attention' to Morton's ideas in Humankind. ${ }^{10}$ Through the application of developments in ambient poetics and the lens of attunement, this essay demonstrates Morton's claim that ambience might allow us to 'not merely figure out but actually experience [...] that we [are] embedded in' the ontology Humankind theorises. ${ }^{11}$

\section{The Symbiotic Real}

Firstly, it is important to understand exactly what kind of ontology Humankind might ask the reader to become attuned to. From the outset of the text, Morton seeks to replace anthropocentric theorisations of ontology with that of the symbiotic real, an ecological conception of being-in-the-world underpinned by OOO. Morton critiques Heidegger's concept of being-in-the-world, as even though he captures being as always contextual and situated, 'he irrationally restricts [this] to humans', therefore destroying any possibility of

\footnotetext{
${ }^{8}$ Ibid., p. 150.

${ }^{9}$ Ibid., p. 152.; Timothy Morton, Being Ecological (London: Pelican Books, 2018), p. 79.

${ }^{10}$ Dovey and Hayler, 'Critical Ambience', p. 156.

${ }^{11}$ Morton, Ecology Without Nature, p. 64.
} 
ecological world-sharing. ${ }^{12}$ In developing being-in-the-world beyond this damaging anthropocentrism, Morton describes how the symbiotic real refers to the state in which entities are related in a non-total, ragged way ... In symbiosis, it's unclear which is the top symbiont, and the relationship between the beings is jagged, incomplete. ${ }^{{ }^{13}}$ In the symbiotic real, all beings within the biosphere, whether they are a human, a tree, a smartphone, or a spoon are partial, incomplete, and constantly engaged in messy co-constitutive relationships with other beings. In these relationships any host / parasite distinction between symbionts starts to seem irrelevant, shifting the emphasis towards a consideration of how beings are mutually entangled in complex symbioses. As Morton puts it, entities are "messy heaps of other things' rather than distinct and independent. ${ }^{14}$

The symbiotic real captures the ontological state which arises from this messy co-dependence. Arising from this constant symbiosis, Morton identifies 'relying-on [as] the uneasy fuel of the symbiotic real', a fact which naturally results in a feeling of 'solidarity' with non-human entities (including spoons). ${ }^{15}$ If we see ourselves as ontologically reliant on all non-humans (and, by the same thinking all other humans), then a feeling of solidarity with those beings naturally follows. The indiscriminate nature of this solidarity potentializes a radical world-sharing. By dissolving any boundaries between what is and isn't deserving of solidarity in the biosphere, Morton suggests that we might prevent the 'large-scale violence' which pervades human actions. ${ }^{16}$

Morton suggests that post-agricultural society has suffered an ontological break in its separation from the symbiotic real, largely stemming from its designation of "nonhuman beings as slaves and food for humans. ${ }^{17}$ Fundamentally, this 'Severing is a ... traumatic fissure between ...reality (the human-correlated world) and the real (ecological symbiosis of human and non-human parts of the biosphere). ${ }^{18}$ Morton's deliberately dramatic coinage of the 'Severing' reframes the dominance of humanism and its philosophical belief, as outlined by Catherine Belsey, that the human subject is 'unified, knowing, ...autonomous', and privileged above all other beings. ${ }^{19}$ Viewing humanism through the lens of Morton's 'Severing' suggests that the humanistic ways in which we are conditioned to perceive the

\footnotetext{
${ }^{12}$ Michael Wheeler, 'Martin Heidegger', in The Stanford Encyclopedia of Philosophy, ed. by Edward N. Zalta, (Fall 2020 Edition), <https://plato.stanford.edu/archives/fall2020/entries/heidegger/>, [accessed o6 March 2021]; Morton, Humankind, p. 9.

${ }^{13}$ Morton, Humankind, p. 1.

14 Verso Books, Timothy Morton in Conversation with Verso (YouTube, 27 Sept 2017) https://www.youtube.com/watch?v=1AEy2KmHwho\&t=1038s [accessed 04 February 2021].

${ }^{15}$ Morton, Humankind, p. 2.

${ }^{16}$ Verso, Morton in Conversation

${ }^{17}$ Morton, Humankind, p. 27.

${ }^{18}$ Morton, Humankind, p. 13.

${ }^{19}$ Catherine Belsey, The Subject of Tragedy (London: Routledge, 1991), p. 8.
} 
world are radically and traumatically separated from how things actually exist. Morton draws a causal link between this 'Severing' and the 'large-scale violence' of current and historical human actions by suggesting that fascism is symptomatic of the refusal to recognise that we ontologically rely on all the beings in the biosphere. ${ }^{20}$

The symbiotic real therefore seeks to refigure our understanding of being-in-the-world, resonating with the pursuit of 'new subjectivities that escape the Cartesian self' identified by Dovey and Hayler in IMHBD's critical ambience. ${ }^{21}$ This resonance begins to refigure ambience as an experiential mode uniquely suited to an undoing of the Severing and attuning the reader to existence within the symbiotic real. We might therefore suggest that the IMHBD's 'environmentally aware modes of attention' have the potential to allow us to 'experience the fact that we [are] embedded in' the symbiotic real, realising the ecocritical potential of ambience by bringing perceptible reality closer to the ontological real. ${ }^{22}$ In the ways in which it cultivates this experience, IMHBD has the potential to go some way towards healing the wounds of the Severing and slowing the proliferation of its trauma, allowing the reader to experience existence within the symbiotic real, not just understand it from some theoretical distance. My close reading of IMHBD traces some of the ways in which a reader might undergo this experiential attunement with Morton's ontology.

\section{Symbiosis and Entanglement}

For Hayler and Dovey, works of ambient literature directly position the reader as 'an agent ... situated within (and as a part of) the environment that the text seeks to discover. ${ }^{23}$ At certain points in the text's guided walk, IMHBD's narrator asks the reader to seek out features of their environment such as places of dwelling, water, or wood, enlisting them to directly engage with the non-human entities that constitute their immediate surroundings. That this request is delivered via audiotext is significant to how the reader goes on to engage with their environment. As Dovey, Abba, and Pullinger identify in their introduction to Ambient Literature, 'when listening to a story the eyes are free to look. The environment of the listener can become the setting for the narrative. ${ }^{24}$ Whilst reading printed text is also always environmentally co-constituted, the freeing of the listener's gaze when engaged with audiotext uniquely facilitates the formation of connections between narrative and the

\footnotetext{
${ }^{20}$ Verso, Morton in Conversation; Morton, Humankind, p. 29.

${ }^{21}$ Dovey and Hayler, 'Critical Ambience', p. 150.

${ }^{22}$ Ibid., p. 156.; Morton, Ecology Without Nature, p. 64.

${ }^{23}$ Hayler and Dovey, 'Critical Ambience', p. 154.

${ }^{24}$ Dovey et. al, 'Introduction', p. 12.
} 
environment in which it is experienced. Through this, the auditory prompts to engage with environmental features alongside the content of $I M H B D$ 's narrative directly involve both listener and their non-human surroundings in processes of literary meaning-making. The resultant, situated literary engagement establishes the means with which to attune the reader to the symbiotic reliance between beings which actualises their being-in-the-world.

This cultivation of attention towards our non-human surroundings resonates with Hayler's work on the entanglement of place, digital artefacts, and literary meaning-making in his chapter in Ambient Literature: 'Objects, Places and Entanglements'. ${ }^{25}$ Hayler defines entanglement as being 'about meaning, action, and agency always being realised by more than one thing at a time', approaching and articulating the complex ways in which all things are related. ${ }^{26}$ For Hayler, $I M H B D$ engages with this entanglement in how it 'guides you to pay attention to all of the things that play into making your experience of your surroundings what it is' asking us to 'look again at our devices' and pay particular attention to 'what they and we rely upon. ${ }^{27}$ This guided attention towards the mutual reliance between humans and digital devices begins to reflect the deep entanglement between all entities in ecological symbioses. By tapping into this co-dependent element of the symbiotic real, Hayler's work suggests that the ubiquity of mutual reliance is ontological as well as social. Whilst our social relations are deeply entangled with digital artefacts, so too are our ontological relations as we welcome our smartphones and other devices into the 'messy heap' of things we refer to as humans. ${ }^{28}$ The being that we identify as the contemporary human subject is increasingly only able to appear as such through a reliance on a complex network of digital artefacts ${ }^{29}$ and the ontological co-constitution that arises from this..$^{30}$ Therefore, the attention that the narration guides towards more obviously ecological entanglements allows IMBHD to raise similar questions of ontological reliance about the reader's environment and the non-human entities which inhabit it. These questions might then help tune the reader's perception into the

\footnotetext{
${ }^{25}$ Hayler, 'Objects, Places, and Entanglements'.

${ }^{26}$ Ibid., p. 78.

${ }^{27}$ Ibid., p. 87.

${ }^{28}$ Verso, Morton in Conversation.

${ }^{29}$ Whilst access to digital technology is increasing, as of January 2021 only $59.5 \%$ of the global population were active internet users and investment in technology still ranges widely across class, ethnicity, disability, and age lines. My identification of a digitally entangled subject corresponds to a significant, but not totalising, portion of the global population: Joseph Johnson, Global digital population as of January 2021 (2021) <https://www.statista.com/statistics/617136/digital-population-worldwide/> [accessed 16 March 2021].

${ }^{30}$ In Challenging the Phenomena of Technology, Hayler identifies our entanglement with digital artefacts as just a new chapter in a long lineage of technological entanglement: Matt Hayler, Challenging the Phenomena of Technology (Hampshire: Palgrave Macmillan, 2015).
} 
complex "relying-on" which fuels the symbiotic real, undermining any semblance of beings as independent of one another.

When the narrator asks the reader to 'find some wood' and to make physical contact with it, it prompts them to similarly 'look again' at an entity which is often encountered as mundane or uninteresting. ${ }^{31}$ This novel mode of engagement refigures wood as newly interesting, recentring the reader's engagement with it as a constituent part of the ambient literary experience. Wood's presence in the reader's surroundings is intensified so that it becomes something which accommodates a deep attention to how it exists within the world. Thus, an ontological attention is constituted, one which forms a key element of the 'different frames of attention' which Hayler and Dovey argue develops IMHBD's ecocritical potential. ${ }^{32}$ The reader's ontological attention is subsequently cultivated and developed through the questions and prompts given by the narrator, creating the conditions in which this new-found deep attention towards non-humans might develop into a profound perceptual change, one which would bring the reader's experience of their surroundings in line with the entangled nuances of Morton's symbiotic real.

For instance, the narrator prompts the listener to think of how the wood they have found is 'a porous thing, absorbing so much from its surroundings', with 'breath and fumes in the air, dust and dirt blown in the wind, sunlight and rain, all leaving their traces' upon its being. ${ }^{33}$ A part of this interaction (depending on where the reader finds themselves at that moment) might involve making the reader think of how a bench might absorb pollution from a nearby road, thereby fundamentally changing its being-in-the-world. This guided attention towards wood's ontological porousness realises a new level of consideration for how all aspects of the world become entangled into wood's being, and reflexively, how wood and the agency that wood enacts upon the world help constitute other (including our own) entangled states of being. An acknowledgement of wood as a 'porous thing', constantly engaged in processes of uneasy symbiosis, therefore begins to shift our perception towards seeing beings as 'messy heaps. ${ }^{34}$ This perceptual change rejects the humanistic notions of the autonomy outlined by Belsey and helps guide the reader towards recognising 'new subjectivities that escape the Cartesian self.' ${ }^{35}$ In its porousness, a bench is constantly engaged in uneasy symbioses with all the beings and processes that surround it, whether that be pollution, humidity or the people that sit on it. The attention drawn by IMHBD to the porousness of the

${ }^{31}$ Duncan Speakman, It Must Have Been Dark By Then (Bristol: Taylor Brothers, 2017), (Audio Narration); Hayler, 'Objects, Places, and Entanglements', p. 87.

${ }^{32}$ Dovey and Hayler, 'Critical Ambience', p. 156.

${ }^{33}$ Speakman (Audio Narration).

${ }^{34}$ Ibid. (Audio Narration); Verso, Morton in Conversation.

${ }^{35}$ Belsey, p. 8.; Dovey and Hayler, 'Critical Ambience', p. 141. 
bench therefore forces the reader to reckon with the fact that the bench's being-in-the-world necessitates entanglement in an innumerable number of non-human symbiotic processes.

This interaction allows the reader to become more acutely aware of the complex, vital, and non-human processes of symbiosis which constantly envelop them. A recognition of these processes lends itself to developing a genuine solidarity with non-human objects through their ontological co-constitution with and of human subjects. Whilst this connection would likely have seemed ridiculous beforehand, the way in which $I M H B D$ 's narrative attunes the reader to symbioses in their surroundings refigures the connection as totally logical. Whether what is found when prompted is a tree, a doorframe, or a bench, the text highlights the way in which those entities are entangled in the ontological processes of mutual reliance central to both Morton's theorisation of ecological ontology and Hayler, and Dovey and Hayler's work on the entangled potential of ambient literature.

\section{Subscendence}

For Morton, an attunement to the entangled, symbiotic nature of being necessarily demands a recognition of what they call 'subscendence', a seemingly counterintuitive claim that 'the whole is always less than the sum of its parts. ${ }^{36}$ As Morton says, 'we keep ... nodding along' when people say: "the whole is always greater than the sum of its parts" ${ }^{37}$ After all, it's just common sense, right? Morton, however, disagrees, arguing that 'this truism is one of the greatest inhibitors of world sharing. ${ }^{38}$ By reckoning with existence as a part of the symbiotic real Morton argues that one must acknowledge that 'parts are not just mechanical components of wholes' and there can be 'be genuine surprise and novelty in the world' in the ways in which parts exist beyond the wholes to which we tend to reduce them. ${ }^{39}$ The language Morton uses to articulate how things subscend the whole is that:

A (all the parts of a thing) 'is so much more than' B (those parts viewed as a whole)..$^{40}$

Therefore, subscendence and the way that things constantly subscend wholes force the reader to reckon with the fact that something like a human, a river, or a phenomenon like climate change or neoliberalism is ontologically smaller than all the parts which make up that whole. This claim leaves room for those parts to wriggle out from the body of the whole

\footnotetext{
${ }^{36}$ Morton, Humankind, p. 101.

${ }^{37}$ Verso, Morton in Conversation

${ }^{38}$ Morton, Humankind, p. 101.

${ }^{39}$ Ibid., p. 102.

${ }^{40}$ Ibid., p. 102.
} 
and to engage with the world on their own terms in new and surprising ways, potentializing real and meaningful change in the world. For instance, through subscendence, a seemingly impenetrable whole such as neoliberalism might become ontologically destabilised and open to new, positive possibilities of change.

The way in which $I M H B D$ 's reader engages with their immediate surroundings is shaped by simultaneous engagement with the memories conveyed in the printed book helps to develop an experience of the world as subscendent. The text's 'underlying notion that whatever you're doing right now, there's someone else doing something similar in a similar location but probably in a totally different social and political context' provides the conditions for entities to be able to wriggle out from being reduced to mechanical parts of a static whole, drawing them into surprising co-existence with and within other entities. ${ }^{41}$ Perhaps the non-human entity in the text which best encourages this experience of the world as subscendent is water. As Hayler identifies, the three locations which the text takes the reader to: Louisiana, the Sahara, and Latvia, are 'each marked by water crises', crises that become palimpsestuously layered over the reader's immediate surroundings. ${ }^{42}$

Given this commonality of water crises, arguably the most critical of these moments of layering is when the narrator asks the reader 'can you find some water now?'43 After guiding the reader towards a similar deep attention towards water's complex being-in-the-world, the narrator asks the reader to open the printed book and, with this ontological attention in mind, to read chapter five: a recount of rising water levels in Louisiana. ${ }^{44}$ Speakman's recounting of his journey to Louisiana highlights the encroachment of the Mississippi river across the state, as the structures designed to contain it begin to fail and the federal government withdraws protection for those subsequently put at risk by this. The palimpsestuous way in which the reader engages with this reality, consciously engaging a water source in their environment, creates a collapse of the distance, both physically and conceptually, between themselves and the water crises highlighted by Speakman's writing. As Hayler says, 'Speakman ... always seems to be saying "that place could be right here; you could be right there". ${ }^{45}$ With this new feeling that the reader could be somewhere else, or that somewhere else could be where they are, the water which they encounter - whether river, pond, canal or drain - is revealed to be so much more than it might at first seem. When

\footnotetext{
${ }^{41}$ Kate Pullinger and Duncan Speakman, 'It Must Have Been Dark by Then: An Artist Interview with Duncan Speakman', in Ambient Literature, ed. by Tom Abba, Jonathan Dovey, and Kate Pullinger (London: Palgrave Macmillan, 2021), p. 104-5.

${ }^{42}$ Hayler, 'Objects, Places, and Entanglements', p. 86.; For more on palimpsests and ambience see: Hayler, 'Objects, Places, and Entanglements'.

${ }^{43}$ Speakman (Audio Narration).

${ }^{44}$ Ibid., pp. 35-46.

${ }^{45}$ Hayler, 'Objects, Places, and Entanglements', p. 92.
} 
read alongside Speakman's account of the worsening flooding crisis in Louisiana, the way the reader situates the water in their surroundings might slip from simply a part of a pond to being a part of a global network of water surplus and deficit, or similarly slip into being a part of the threat of rising water levels through the text's palimpsestuous layering. If, for instance, the reader is situated by the river Thames in this moment of layering, suddenly that river might become the Mississippi menacingly meandering through the centre of London, it might be rising upwards towards buildings, it might become a threat. The line between text and environment becomes porous, at moments seeming to collapse altogether as features of Louisiana become features of the reader's surroundings. In this way, IMHBD allows, previously rigid boundaries between separate wholes to morph and collapse, as Hayler states allowing different perceived realities to live 'on top of one another', driving the things which surround the reader to subscend any reduction to mechanical parts of static wholes. ${ }^{46}$

The way that $I M H B D$ introduces subscendence ensures that the experience of tuning into this aspect of the symbiotic real is an intensely, 'critically focused experience. ${ }^{47}$ By subverting one of the 'greatest inhibitors of world sharing' in the way that the reader perceives their surroundings, IMHBD facilitates a greater ability to undo the 'Severing', and therefore to share our world with non-humans. ${ }^{48}$ For Morton, a recognition of subscendence in the world is necessarily a recognition that 'humankind is a fuzzy, subscendent whole that includes and implies other lifeforms. ${ }^{49}$ As the reader experiences $I M H B D$, it becomes clear that surprise, novelty, and change are present in the world beyond human correlation, in rivers, in benches, in spoons, even within their own body. This final point totally undermines any humanistic categorisation of the human subject as 'unified ...and autonomous', going some way towards healing the trauma of the "Severing". ${ }^{50}$

\section{Conclusion - The Walk Back}

Towards the end of $I M H B D$, the reader reaches 'the edge of [their] map', 'the furthest point of [their] journey. ${ }^{51}$ This does not mark the end of the text, however. At this moment of seeming finality, the narrator tells the reader that 'every person that walks these stories will create their own map, but this one is yours. And this is the moment where you'll walk

\footnotetext{
${ }^{46}$ Ibid., p. 92.

${ }^{47}$ Dovey and Hayler, 'Critical Ambience', p. 141.

${ }^{48}$ Morton, Humankind, p. 101.

${ }^{49}$ Ibid., p. 120.

${ }^{50}$ Belsey, p. 8.

${ }^{51}$ Speakman (Audio Narration).
} 
through it. ${ }^{32}$ The reader puts away their book, looks away from the screen of their device and retraces the route they took to get from where they started to the edge of their map, guided only by the narration that continues to play in their headphones. This walk back draws together all the perceptual shifts that the text has facilitated, leaving those changes not as entirely intelligible, literary mediation, but simply as a new, completely sensible way of existing within the world. This unmediated feeling of the return walk is captured in the testimony of an $I M H B D$ reader:

When ... I was told to walk back, I was worried that I wouldn't know the way but then when I started walking my body just told me. ${ }^{53}$

It is in this largely unguided, physically intuitive process of returning to the start of their "map" that the text most fully realises the ontological attunement which has underpinned this essay. The attention cultivated towards symbiosis and subscendence on the walk out doesn't simply evaporate away from an engagement with page and screen. Instead, these two features of the symbiotic real are tied together and manifested in a feeling of indiscriminate solidarity with non-human entities. Morton terms this 'inner dynamic of action based on a readily available solidarity that includes non-humans' 'rocking'. ${ }^{54}$ When the reader walks back towards the point where they first opened the app, they walk back in a state much closer to "rocking" than they would have prior to encountering $I M H B D$, thus bringing their reality closer to the (symbiotic) real. Whilst Morton usefully theorises this state, using it to call for a new 'theory of action' in philosophy, IMHBD extends it by providing the means to realise "rocking" as immediate experience..$^{55}$ This phenomenological solidarity with the ecological world imbues non-humans with a sense of vibrancy in the way that they adapt beyond human correlation: wriggling, shifting, and enacting real and meaningful agency through symbiosis and subscendence. ${ }^{56}$ Put simply, as the reader walks back the world's newly revealed ecology appears more exciting and joyful in its expansive vitality and possibility.

This ability to joyfully experience ecological ontology, using IMHBD's ambient poetics to develop "rocking" as a lived phenomenology of the symbiotic real, extends both 'Critical Ambience' and Humankind's projects. For 'Critical Ambience', the fact that the text might refigure the reader's perception of something so vital as ontology is a clear refutation

\footnotetext{
$5^{2}$ Ibid.

${ }^{53}$ Pullinger and Speakman, 'It Must Have Been Dark by Then', p. 111.

${ }^{54}$ Morton, Humankind, p. 179.

55 Ibid., p. 188.

${ }^{56}$ For more on the ontological "vibrancy" of objects see: Jane Bennet, Vibrant Matter: A Political Ecology of Things (Durham: Duke University Press, 2009).
} 
of ambient poetics as simply 'passive backgrounds or immersive entertainment. ${ }^{57}$ The attunement of a reader to such a radical ontology is an intensely critical practice, demonstrating the relevance of Dovey and Hayler's discussion of ecology and ambience to future projects engaged with similar concerns. For Humankind, reintroducing the idea that ambient poetics might allow us to 'experience the fact that we [are] embedded in' ecology enables Morton's project of developing a new radical ontology to become more fully realised by smoothly attuning the reader's perception to its nuances. ${ }^{58}$ When combined with other artworks and a mainstreaming of ecological thought, the ontological attunement which $I M H B D$ facilitates might form a key mode in which the trauma of the 'Severing' can be undone. ${ }^{59}$ This essay's folding-together of the two fields reveals how IMHBD's ambient poetics enables the reader to not just know the ontology of the symbiotic real, but to live it.

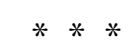

\section{Works Cited}

Belsey, Catherine, The Subject of Tragedy (London: Routledge, 1991).

Bennet, Jane, Vibrant Matter: A Political Ecology of Things (Durham: Duke University Press, 2009).

Dovey, Jonathan, Matt Hayler, 'Critical Ambience', in Ambient Literature, ed. by Tom Abba, Jonathan Dovey, Kate Pullinger (London: Palgrave Macmillan, 2021).

Dovey, Jonathon, Tom Abba, and Kate Pullinger, 'Introduction', in Ambient Literature, ed. by

Tom Abba, Jonathan Dovey, Kate Pullinger (London: Palgrave Macmillan, 2021). Eliasson, Olafur, Ice Watch, 2014 (2014) https://olafureliasson.net/archive/ artwork/WEK109190/ice-watch/ [accessed 16 March 2021]. Eno, Brian, Music for Airports / Ambient 1, (LP Liner Notes) (London, Polydoor, 1978). Harman, Graham, Object-Oriented Ontology A New Theory of Everything (London: Pelican Books, 2018).

\footnotetext{
${ }^{57}$ Dovey and Hayler, 'Critical Ambience', p. 141.

${ }^{58}$ Morton, Ecology Without Nature, p. 64.

${ }^{59}$ Such as Olafur Eliasson's Ice Watch, an ecological art installation created with participation from Morton: Olafur Eliasson, Ice Watch, 2014 <https://olafureliasson.net/archive/artwork/WEK10 919o/ice-watch/> [accessed 16 March 2021]; Morton, Being Ecological, pp. 86-87.
} 
Hayler, Matt, Challenging the Phenomena of Technology (Hampshire: Palgrave Macmillan, 2015).

—, 'Objects, Places, and Entanglements ', in Ambient Literature, ed. by Tom Abba,

Jonathan Dovey, Kate Pullinger (London: Palgrave Macmillan, 2021), p. 87.

Hayles, N. Katherine, 'Hyper and Deep Attention: The Generational Divide in Cognitive Modes', Profession (2007), 187-199 (p. 187).

Johnson, Joseph, Global digital population as of January 2021 (2021) https://www.statista. com/statistics/617136/digital-population-worldwide/ [accessed 16 March 2021].

Morton, Timothy, Being Ecological (London: Pelican Books, 2018).

— Ecology without Nature (Massachusetts: Harvard University Press, 2009).

- Humankind (London: Verso, 2017).

Pullinger, Kate, Duncan Speakman, 'It Must Have Been Dark by Then: An Artist Interview with Duncan Speakman', in Ambient Literature, ed. by Tom Abba, Jonathan Dovey, Kate Pullinger (London: Palgrave Macmillan, 2021).

Speakman, Duncan, It Must Have Been Dark By Then (Bristol: Taylor Brothers, 2017).

Verso Books, Timothy Morton in Conversation with Verso (YouTube, 27 Sept 2017) https:// www.youtube.com/watch?v=1AEy2KmHwho\&t=1038s [accessed 04 February 2021].

Wheeler, Michael, 'Martin Heidegger', in The Stanford Encyclopedia of Philosophy, ed. by Edward N. Zalta, (Fall 2020 Edition), https://plato.stanford.edu/archives/

fall2020/entries/heidegger/, [accessed o6 March 2021]. 